Kamilla Frejusz

Papieski Wydziae Teologiczny Collegium Bobolanum

WARSZAWA

\title{
MAGIS 2016 - JEZUICKA PROPOZYCJA FORMACJI MŁODZIEŻY UCZESTNICZĄCEJ W ŚWIATOWYCH DNIACH MŁODZIEŻY
}

Jak dziś przygotowywać ludzi młodych do Światowych Dni Młodzieży, aby nie były one jednorazowym (aczkolwiek cyklicznie powtarzającym się i niewątpliwie pełnym radości i entuzjazmu) wydarzeniem katechetycznym? Jaki rodzaj formacji opartej wokół tego wydarzenia proponować, aby nie było ono przeżywane jedynie w sferze uczuć i emocji ale autentycznie prowadziło ludzi młodych do spotkania z Bogiem, tę relację umacniało, a nawet było zachętą do jej pogłębiania w codziennym życiu? Te pytanie niewątpliwie nurtują dziś nie tylko kapłanów, katechetów oraz samych organizatorów tego wydarzenia. Również liczne zgromadzenia zakonne jak i wspólnoty świeckich poszukują inspiracji do katechezy ludzi młodych przygotowujących się do udziału w Światowych Dniach Młodzieży. Stąd też liczne inicjatywy, podejmowane już dziś w całym Kościele, mające na celu wyjście ku młodym nie tylko na czas Światowych Dni Młodzieży ale przede wszystkim w czasie poprzedzającym to wydarzenie. Wśród wielu propozycji, jakie Kościół przedstawia dziś ludziom młodym w kontekście Światowych Dni Młodzieży, znajduje się także program MAGIS Towarzystwa Jezusowego (Jezuitów), a szczególnie proponowane w nim ignacjańskie eksperymenty.

\section{Historia programu MAGIS}

Jezuici prowadzą program MAGIS od 1997 r. z myślą o młodych z całego świata, którzy uczestniczą w Światowych Dniach Młodzieży. Idea i powstanie tego programu niejako rodziły się w trakcie poszczególnych spotkań papieży z ludźmi młodymi. Wśród jezuitów, którzy wraz z młodymi przyjeżdżali na kolejne edycje tego wydarzenia, zrodził się pomysł, aby wykorzystać tę okazję do integracji młodzieży na poziomie międzynarodowym. W 1997 roku zorganizowano ignacjańską pielgrzymkę, w której młodzi z różnych krajów, przez kilka dni wędrowali do stolicy Francji. W roku 2000, włoscy jezuici udoskonalili tę propozycję i zorganizowali międzynarodową pielgrzymkę "gwiaździstą”. Młodzi pielgrzymi wyruszyli w kierunku Rzymu z kilku różnych miejsc jednocześnie. W 2005 roku, w Niemczech, 
wykrystalizowała się zasadnicza forma jezuickiego programu przygotowawczego do ŚDM: kilka dni różnych aktywności (tzw. ignacjańskie eksperymenty), które kończą się wspólnym świętowaniem oraz udziałem w Światowych Dniach Młodzieży. Wtedy również program przyjął nazwę MAGIS. W Sydney, Madrycie i Rio odbyły się kolejne edycje tego programu. Gdy w Brazylii, papież Franciszek, ogłosił, że to Kraków będzie gościł kolejne Światowe Dni Młodzieży, również polscy jezuici przyjęli zadanie zorganizowania MAGIS $2016^{1}$.

\section{Nazwa programu}

Nazwa programu wywodzi się od łacińskiego słowa magis, które jest „tłumaczeniem ważnego i drogiego dla św. Ignacego Loyoli, hiszpańskiego słowa mas, co można przełożyć jako: więcej, bardziej”². Pierwsze rozumienie słowa magis, oznaczające „więcej” nie oznacza „porównania z innymi ani mierzenia postępu według pewnego absolutnego poziomu. Chodzi raczej o możliwie najpełniejszy rozwój pojedynczej osoby na każdym etapie jej życia, wraz z gotowością kontynuowania rozwoju poprzez całe życie oraz motywację spożytkowania rozwijanych darów dla

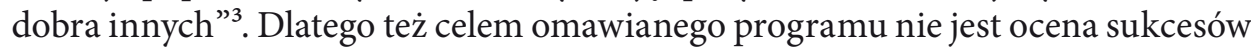
lub porażek młodych ludzi, lecz przede wszystkim pomaganie im w odkrywaniu siebie samych ${ }^{4}$. Drugie rozumienie słowa magis jako „bardziej”, odnajdujemy w Ćwiczeniach duchowych. Słowo to umieszczone jest w ścisłym związku z celem

\footnotetext{
1 Program MAGIS 2016 (będący polską wersją jezuickiego programu MAGIS) obejmie okres bezpośrednio poprzedzający Światowe Dni Młodzieży w Krakowie: 15-25 lipca 2016 roku. W skład osób tworzących ignacjańskie eksperymenty wchodzą: lider eksperymentu (jest bezpośrednio odpowiedzialny za grupę oraz przebieg eksperymentu dzień po dniu, kontaktuje się instytucjami i osobami prywatnymi, organizuje stronę logistyczną (noclegi, wyżywienie, ewentualnie transport lokalny) eksperymentu, jest także odpowiedzialny za część duchową eksperymentu), wolontariusze (wspierają lidera w kwestiach praktycznych i logistycznych, towarzyszą uczestnikom, dając im wsparcie i instrukcje), warsztatowiec - osoba odpowiedzialna za organizację działania, kapłan (Jezuita) - osoba odpowiedzialna za sprawowanie Mszy Świętej oraz innej posługi sakramentalnej, pomaga liderowi eksperymentu w części w duchowej formacji uczestników, uczestnicy (około 25 młodych osób w wieku 18-30 lat z trzech lub czterech różnych krajów). Ignacjańskie eksperymenty prowadzone w ramach MAGIS 2016 przygotowywane są dla ok. 2000 ludzi młodych, związanych z jezuickimi ośrodkami duszpasterskimi. Por. Broszura..

2 J. Mółka, B. Steczek, Magis jezuickiej edukacji, w: Pedagogika ignacjańska wobec wyzwań współczesnego humanizmu, red. W. Pasierbek, Kraków 2008, s. 237.

3 Charakterystyczne cechy jezuickiego wychowania, Kraków 1989, p. 109.

4 Por. Wytyczne do programu MAGIS 2016 (Jest to wewnętrzny dokument, którym posługują się koordynatorzy MAGIS 2016. Stanowi on główny punkt odniesienia w artykule ponieważ jest jedynym programowym dokumentem. Nie został on oficjalnie opublikowany w żadnej formie ani papierowej, ani cyfrowej - a jedynie udostępniony autorce artykułu w celach badawczych. Ze względu na swą małą objętość nie jest podzielony na części ani numery. W dalszej części artykułu dokument ten określany będzie skrótem WPM).
} 
życia człowieka, którym dla św. Ignacego jest Bóg i osiągnięcie zbawienia. Świat, w którym żyje człowiek może pomóc mu w realizacji jego ziemskiej misji, o ile wybiera on rzeczy, które do tego ostatecznego celu prowadzą. Ignacy nie domaga się tutaj ucieczki od świata, a wręcz proponuje zaangażowanie w jego sprawy, wreszcie coraz lepsze poznawanie go. Wszystko to ma służyć realizacji planu zbawienia $^{5}$. To zaangażowanie się w sprawy świata oraz poznawanie go znajduje swoje odzwierciedlenie właśnie w idei i założeniach programu MAGIS. Twórcy programu podkreślają, iż jego nazwa wyraża także jedną z podstawowych ludzkich cech, jaką jest pragnienie czegoś więcej. Z tego pragnienia człowiek czerpie siłę do ciągłego rozwoju. Ignacjańskie magis znaczy jednak jeszcze coś więcej. Założyciel zakonu jezuitów używał tego słowa, także aby pokazać, że „autentycznie przeżywane chrześcijaństwo jest rzeczywistością niezwykle dynamiczną. Przyjaźń z Bogiem oraz służba bliźniemu to kwestie, które domagają się ciągłego wzrostu. Ten, kto poddaje się inspiracji magis wykracza poza interes osobisty i dąży do osiągnięcia dobra uniwersalnego. Chodzi tu o realizację Królestwa Bożego w historii; o coraz głębsze przyjmowanie daru zbawienia po to, by móc go przekazywać drugiemu człowiekowi; o to, by żyć na większą chwałę Boga. Człowiek magis - wsłuchany w Słowo Boże i rozróżniający wewnętrzne poruszenia - podejmuje ryzyko i wychodzi poza to, co już poznane, zdefiniowane, oczekiwane. Nieustannie otwiera się na nowe, gdyż czuje, że, to Jezus Chrystus wzywa go takiego, jakim jest, aby czynem i słowem głosił bliźnim Dobrą Nowinę o zbawieniu”". Dlatego też ignacjańskie magis, zdaniem W. Lamberta, powinno „być tłumaczone jako „dalej”: rośnij dalej, kochaj bardziej, idź dalej. Pierwszym krokiem, ku któremu prowadzi to „dalej”, jest krok wyjścia poza czysto egoistyczne zajęcie się samym sobą ${ }^{7}$. Stąd też program ten w swoich założeniach skupia się na propozycjach różnych aktywności na rzecz innych, które mają doprowadzić do osobowego i duchowego rozwoju uczestników. Pojęcie magis oznacza bowiem całościowy rozwój, wychowanie, które „zakłada formację osoby w jej całokształcie.(...)W swojej istocie pojęcie to wyklucza jakiekolwiek bierne przyjmowanie np. wiedzy, bowiem magis odnosi się nie tylko do teorii, ale i działania"8. Dlatego też program ten zakłada bycie we wspólnocie i naukę współpracy, a także gromadzenie doświadczeń prowadzących do refleksji ${ }^{9}$. Program MAGIS to także pomoc młodemu człowieku w tak ważnym dla niego okresie wzrastania, rozumianym w szerokim słowa tego znaczeniu. Jak podkreśla generał Jezuitów, „to słowo (magis) odpowiada bardzo ważnej zasadzie

5 Por. P. Łacny, Jezuickie magis na przykładzie życia ojca Matteo Ricciego SJ (1552-1610), w: Pedagogika ignacjańska. Historia. Teoria. Praktyka, red. A. Królikowska, Kraków 2010, s. 152-153.

6 WPM.

7 W. Lambert, Słownik duchowości ignacjańskiej, Kraków 2001, s. 15.

8 B. Topij-Stempińska, Geneza pedagogiki ignacjańskiej, w: Pedagogika ignacjańska. Historia. Teoria. Praktyka, dz. cyt., s. 87.

9 Por. WPM. 
u św. Ignacego - że życie ludzkie to wzrastanie. Jeśli nie wzrastamy, karlejemy, umniejszamy się. Życie jest ciągłym wzrastaniem. Jeśli ktoś nie rośnie, to dzieje się coś niedobrego. (...) Św. Ignacemu chodzi o więcej Chrystusa, o Chrystusowe więcej. Więcej Boga, więcej Tajemnicy, więcej innych. (...) więcej Boga oznacza też mniej nas. (...) Mniej nas samych, żeby móc spotkać prawdziwe ja, które jest w Bogu. (...) Dawać więcej, kochać więcej i służyć więcej dopóki Królestwo Boże nie stanie się widzialne pośród nas. ${ }^{10}$ "

Mottem, jakie przyświeca programowi MAGIS 2016 są słowa „to give and not to count the cost" (tłum. dawać, a nie liczyć) pochodzące z modlitwy o hojność, której autorstwo przypisuje się św. Ignacemu Loyoli: „Słowo Odwieczne, Jednorodzony Synu Boży, proszę Cię, naucz mnie służyć Ci tak, jak tego jesteś godzien. Naucz mnie dawać, a nie liczyć, walczyć, a na rany nie zważać, pracować, a nie szukać spoczynku, ofiarować się, a nie szukać nagrody innej prócz poczucia, że spełniłem Twoją najświętszą wolę. Amen"11. W ten sposób twórcy programu MAGIS 2016 interpretują motto Światowych Dni Młodzieży w Krakowie: „Błogosławieni miłosierni, albowiem oni miłosierdzia dostąpia (Mt 5,7). Być miłosiernym to posiadać hojne serce. Takie serce daje, a nie liczy. Właśnie takim sercem Maryja przyjęła i odpowiedziała na Słowo Ojca. Takie jest serce Jezusa, w którym objawia się nam Boża miłość. Duch Święty pragnie kształtować takie serce w każdym z nas"12.

\section{Idea ignacjańskich eksperymentów}

Inspiracją ignacjańskich eksperymentów (proponowanych w programie MAGIS 2016) jest jezuicka formacja, a konkretnie tzw. próby (od łac. experimentum). Jak czytamy w konstytucjach Towarzystwa Jezusowego św. Ignacy podkreślał iż „zanim ktoś zostanie przyjęty do domu czy do kolegium albo już po przyjęciu, wymaga się - oprócz wielu innych - sześciu szczególnych prób"13. Dziś w formacji jezuickiej próby te, to konkretne zadania i doświadczenia, którym musi sprostać jezuita będący w okresie formacji, Jest to czas, w którym zleca się (głównie dla zdobycia konkretnego doświadczenia) różnorakie zadania i prace apostolskie, w którym też zakon ma możliwość weryfikacji przydatności kandydata do przyszłej pracy. Próby te służą także rozeznaniu, na jakim polu działalności apostolskiej dany jezuita mógłby pracować i jednocześnie osiągać jak najlepsze wyniki. Wśród tych prób odnajdujemy m.in. 30-dniowe rekolekcje w milczeniu, próbę domową (jest to pierwszy wyjazd do domu po zakończeniu nowicjatu, mający na celu zweryfiko-

\footnotetext{
10 A. Nicolas, Spotkanie z młodzieżą. Gliwice 29 września, w: Wizyta Ojca Generała Adolfo Nicolasa SJ w Polsce. 23-30 września 2012 roku, 2013, s. 86.

11 WPM.

12 Tamże.

13 Konstytucje Towarzystwa Jezusowego 63.
} 
wanie podjętej przed rokiem decyzji o wstąpieniu do zakonu), próbę katechetyczną (miesięczny wyjazd do parafii jezuickiej, zakładający uczenie katechezy oraz włączenie się w życie duszpasterskie parafii), próbę pielgrzymią czy też próbę szpitalną

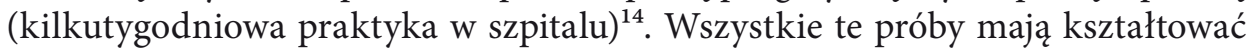
umiejętność dostrzeżenia, na ile człowiek jest wierny swojej relacji z Bogiem, a jednocześnie zdolnym do znajdowania Go we wszystkich rzeczach. Z założenia próby mają stawiać człowieka w sytuacjach trudnych, ale takich, z których można wyjść z pozytywnym doświadczeniem i dać Bogu swoje bardziej świadome, ostateczne i wolne „tak”" Właśnie stąd pochodzi inspiracja ignacjańskich eksperymentów w programie MAGIS 2016. Jak podkreślają twórcy programu, „chodzi o to, żeby wprowadzić młodych ludzi w niecodzienną rzeczywistość eksperymentu (pielgrzymka, duchowość, służba, dialog społeczno-kulturowy, sztuka) oraz mądrze towarzyszyć im w zmaganiach z tym związanych. Poprzez modlitwę, refleksję oraz dzielenie, konkretne aktywności, które podejmują uczestnicy eksperymentów, stają się świadomie przeżytymi doświadczeniami, umocowanymi w relacji z Bogiem i we wspólnocie Kościoła. Międzynarodowy skład grupy eksperymentalnej (3-4 języki w jednej grupie), sprawia, że młodzi bardzo się wzajemnie wzbogacają i realnie doświadczają powszechności Kościoła"16. Dlatego też program MAGIS 2016 zawiera 5 kategorii eksperymentów: pielgrzymkowy, z duchowości, służby (socjalny lub ekologiczny), społeczno-kulturowy oraz artystyczny.

W eksperymencie pielgrzymkowym uczestnicy wraz z Chrystusem przeżywają radości i trudy drogi. W tym czasie dźwigają oraz dbają o niezbędne im w tych dniach rzeczy. Trasa pieszego eksperymentu liczy od 80 do $110 \mathrm{~km}$ (mogą być 4 dni wędrówki i/lub 1 dzień przerwy). Eksperyment ten otwiera także możliwość podróży rowerami, kajakami oraz żeglugi ${ }^{17}$. Aspekt pielgrzymowania to niezwykle ważny element duchowości ignacjańskiej, na której opiera się idea eksperymentów. Na swojej drodze życia św. Ignacy widział siebie jako pielgrzyma. Stąd też pojmował pielgrzymowanie jako osobiste doświadczenie duchowe, czego przykładem było m.in. podpisywanie swoich listów słowem „Pielgrzym”, czy też fakt, że jego auto-

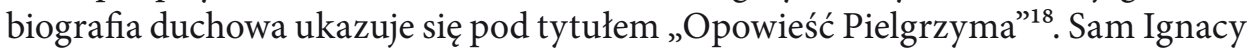
zanim doszedł do przekonania, jak powinno wyglądać jego życie po nawróceniu, wiele pielgrzymował, szukając w tej formie ascezy kontaktu z Bogiem. Stąd też wymiar pielgrzymowania w duchowości ignacjańskiej odnosi się nie tylko do aspektu doświadczenia duchowego ale także symbolizuje duchową pielgrzymkę, którą sam Ignacy odbył od postawy „człowieka światowego” do chrześcijanina

\footnotetext{
14 Por. J. Kołacz, Słownik języka i kultury jezuitów polskich, Kraków 2006, ss. 217-218.

15 Por. P.H. Kolvenbach, Formacja jezuity. Dokumenty, Rzym 2003, s. 23.

16 WPM.

17 Por. WPM.

18 Por. W. Lambert, Słownik duchowości ignacjańskiej, dz. cyt., s. 13.
} 
„walczącego pod sztandarem krzyża”19. Takiemu doświadczeniu mają też zostać poddani uczestnicy tego eksperymentu. Poprzez drogę, pielgrzymowanie i towarzyszącą temu modlitwę mogą zobaczyć swoje życie, na ile jest w nim miejsca dla Boga i innych ludzi.

Celem kolejnego eksperymentu, eksperymentu z duchowości, jest doświadczenie głębokiej modlitwy. Uczestnicy zapoznawani są z różnymi tradycjami chrześcijańskimi. Często modlitwa łączona jest również z pracą. Główny akcent tego eksperymentu skierowany jest na rozwój duchowy ${ }^{20}$. Doświadczenie głębokiej modlitwy, jakie przyświeca idei tego eksperymentu to kolejny aspekt wychowania jezuickiego, w którym podkreśla się, że „modlitwa jest wyrazem wiary i skuteczną drogą zmierzającą do nawiązania osobistej więzi z Bogiem. Prowadzi też do zaangażowania się w służbie innym ludziom. Jezuickie wychowanie daje możliwość stopniowego wprowadzania w modlitwę. Bierze przykład z Chrystusa, który w modlitwie zwracał się regularnie do Ojca. Wszyscy są zachęcani do wielbienia Boga i dziękowania $\mathrm{Mu}$ na modlitwie, do modlitwy jedni za drugich we wspólnocie wychowawczej i do próśb kierowanych do Boga o pomoc w potrzebach całej ludzkiej wspólnoty"21. Tym wezwaniom poddani są także uczestnicy eksperymentu z duchowości.

Eksperyment służby w założeniu programu polega na niesieniu pomocy innym. Może to być praca dla człowieka, działania rozwijane we współpracy z organizacjami rządowymi, pozarządowymi oraz partnerami Towarzystwa Jezusowego. Ważną przestrzenią służby w tym eksperymencie jest środowisko naturalne. Polega on na skłonieniu młodego człowieka do poznania i troski o środowisko naturalne oraz wszystkie stworzenia. Ten rodzaj eksperymentu pomaga uczestnikom kontemplować również Boga w przyrodzie ${ }^{22}$. Postawa kształtowana podczas tego eksperymentu - „być dla innych, cura personalis” podejmowana w dynamice ignacjańskiego modelu wychowania jest odzwierciedleniem postawy Ignacego Loyoli, którą opisuje się słowami „kochać i służyć we wszystkim”. Jest to jednocześnie realizacja charyzmatu ignacjańskiego nazywanego często mistyką służby, służby mającej na celu dobro drugiego ${ }^{23}$.

Kolejny eksperyment społeczno-kulturowy to przede wszystkim czas spędzany z innymi grupami religijnymi, kulturowymi i społecznymi. Ma on na celu dialog z kulturą naszego kraju (tradycjami poszczególnych regionów) oraz wspólnotami religijnymi. Eksperyment ten, to także potwierdzenie, że „jezuickie wychowanie popiera i rozwija dialog między wiarą i kulturą, obejmujący również swym

\footnotetext{
19 J. Kołacz, Słownik języka i kultury jezuitów polskich, dz. cyt., s. 198.

20 Por. WPM.

21 Charakterystyczne cechy jezuickiego wychowania, dz. cyt., p. 67.

22 Por. WPM.

23 Por. E. Dybowska, „Kochać i służyć we wszystkim” idea pomagania duszom (ludziom) w pedagogice ignacjańskiej, w: Nauka-Etyka-Wiara 2009. Konferencja Chrześcijańskiego Forum Pracowników Nauki, red. A. Zabołotny, Warszawa 2009, s. 66.
} 
zasięgiem dialog między wiarą i nauką. Dialog ten uznaje, że zarówno osoby jak i struktury kulturalne są ludzkie, niedoskonałe, czasem dotknięte grzechem i potrzebują nawrócenia. Jednocześnie odkrywa Boga objawiającego się w różny sposób w świecie kultury. Dlatego jezuickie wychowanie popiera kontakty z innymi kulturami i odnoszenie się do nich ze szczerym szacunkiem, by móc krytycznie i twórczo oceniać ich wkład i ich braki" ${ }^{24}$.

Ostatni już eksperyment artystyczny z kolei to okazja do zaangażowania się w różne rodzaje sztuki: malarstwo, architekturę, plastykę, sztukę ludową, pisanie Ikon, aktorstwo, muzykę, śpiew oraz inne. To działania mające na celu pobudzić kreatywność uczestników ${ }^{25}$. Eksperyment ten to jednocześnie odpowiedź na jedno z prioretytowych zadań wychowania w proponowanym modelu pedagogii chrześcijańskiej, jakim jest troska o wielostronny wzrost każdej osoby. W myśl tej pedagogiki „wszyscy uczestnicy są zobowiązani do nieustannego, wnikliwego, bardziej skutecznego rozwijania i udoskonalania własnych zainteresowań, uzdolnień i predyspozycji. W ten sposób będzie realizowany jeden z głównych postulatów pedagogiki ignacjańskiej, aby zadbać o integralny osobowy rozwój i nieustanie dążyć do stawania się bardziej człowiekiem, czyli być „dla innych” i „z innymi” ${ }^{26}$.

Będąc przydzielonymi do konkretnych eksperymentów uczestnicy MAGIS 2016 przez pięć pełnych dni mają możliwość wejścia w polską (ale także litewską, czeską lub słowacką - również w tych krajach odbywać się będzie MAGIS 2016) rzeczywistość społeczną, kulturalną, edukacyjną, duchową, itp. Ich wyzwaniem jest konieczność zafunkcjonowania w napotkanym świecie i w życiu osób, z którymi będą przebywać, „będą odkrywać samych siebie, Boga i drugiego człowieka w miejscach, do których zostaną skierowani. Będą mieli okazję odkryć radość bycia posłanym i rozpalić w sobie pragnienie, by silniej kochać i lepiej służyć"27. Jak podkreślają koordynatorzy programu MAGIS 2016, doświadczenie i działanie podczas proponowanych eksperymentów mają prowadzić każdego uczestnika do codziennej refleksji. Każdego dnia refleksja ta skupia się wokół innych wartości, tak istotnych dziś dla młodych oraz ich relacji z Bogiem. W ten sposób przeżywając wspólną drogę mają możliwość uczyć się czegoś więcej o sobie, otaczającym ich świecie oraz odkrywać głębszy i pełniejszy sens swojego życia. Stąd też eksperymenty wymagają i zakładają elementy działania i współpracy. Młodzi biorący w nich udział poddawani są pewnym próbom i podejmują ryzyko porażki, które może jednocześnie prowadzić ich do odkrycia czegoś więcej w swoich motywacjach

${ }^{24}$ Charakterystyczne cechy jezuickiego wychowania, dz. cyt., p. 38.

25 Por. WPM.

26 J. Mółka, Samorealizacja w założeniach pedagogiki ignacjańskiej, w: Pedagogika ignacjańska. Historia. Teoria. Praktyka, dz. cyt., s. 246.

27 WPM. 
i ich relacji z Bogiem. W tym czasie młodzi przekraczają własne granice, aby być bliżej Chrystusa i ludzi ${ }^{28}$.

\section{Podstawowe elementy ignacjańskich eksperymentów.}

Ignacjański model pedagogiki to dynamika kontekstu, doświadczenia, refleksji, działania i oceny. W ten paradygmat, wzorzec, czy też strukturę, jak zauważa W. Żmudziński można wpisać treść każdego programu nauczania, długoterminowe projekty edukacyjne, prowadzone lekcje, a nawet styl pracy personelu zarządzającego szkołą ${ }^{29}$. Ten paradygmat znalazł także swoje zastosowanie w podstawowych elementach ignacjańskich eksperymentów. Choć w założeniach programu każdy lider eksperymentu ma swobodę w prowadzeniu go zgodnie z własną kreatywnością i możliwościami, niektóre aspekty są jednak wspólne dla wszystkich spotkań. I tak każdego dnia uczestnicy mają określony czas na realizację 5 elementów programu MAGIS, do których należą: osobista modlitwa, aktywizacja/działanie/doświadczenie apostolskie, msza święta, krąg MAGIS (grupki dzielenia) oraz ignacjański rachunek sumienia (indywidualne podsumowanie dnia). W odniesieniu do tych elementów, w trakcie trwania eksperymentów program zakłada realizację następujących aspektów: wspólnotowe przeżywanie eksperymentu, uczestnictwo w życiu społeczności lokalnej, wymiar apostolski (duchowy/społeczny/kulturowy/intelektualny), towarzyszenie młodym (pomoc w pokonywaniu barier) oraz szacunek dla różnorodności. Istotnym elementem ignacjańskich eksperymentów jest także ocena dnia przez organizatorów. Jak podkreślają współtwórcy programu na koniec każdego dnia ważne jest spotkanie lidera eksperymentu z wolontariuszami i animatorami podgrup językowych. Ich celem jest podsumowanie dnia, zauważanie dobrych rzeczy oraz trudności, wysłuchanie opinii i wspólne wyznaczenia zadań i misji na kolejny dzień. Jest to jednocześnie okazja, by podsumować, jak każdy młody człowiek przeżywa ignacjański eksperyment i udoskonalać jego realizację z dnia na dzień ${ }^{30}$.

Kolejnym, istotnym elementem programu MAGIS, wynikającym niewątpliwie z założeń pedagogiki ignacjańskiej, nazywanej również „pedagogiką wolności i osobistej kreatywności”31 jest przekazanie pewnej odpowiedzialności za realizację eksperymentu samym jego uczestnikom oraz wolontariuszom. W myśl programu „konieczne jest zwrócenie uwagi na aktywność uczestników, by nie byli oni jedynie

\footnotetext{
28 WPM.

29 W. Żmudziński, Fundament ignacjańskiej pedagogiki, w: Pedagogika ignacjańska wobec wyzwań współczesnego humanizmu, dz. cyt., s. 60.

30 Por. WPM.

31 J. Augustyn, Ćwiczenia duchowne jako podstawa pedagogiki ignacjańskiej, w: Pedagogika ignacjańska. Historia. Teoria. Praktyka, dz. cyt., s. 20.
} 
pasywni, ale stali się elementem wiodącym (bohaterami eksperymentu). Należy zaprosić ich do współtworzenia tego doświadczenia. Traktować jako młodych, ale już dorosłych ludzi”32.

\section{Duchowość ignacjańskich eksperymentów.}

Ignacjańskie Eksperymenty i duchowość, jaka jest w nich realizowana bazują na doświadczeniu życia świętego Ignacego Loyoli. Wchodząc w odmienne i mało znane sytuacje Ignacy nauczył się patrzeć w nowy sposób na Boga, siebie i innych ludzi. To z tego doświadczenia wypływają jego słowa zachęty kierowane do powierzonych mu młodych ludzi: „Niech się wszyscy starają mieć czystą intencję nie tylko co do stanu swego życia, ale także co do wszystkich poszczególnych spraw, zawsze to w nich mając szczerze na oku, aby służyć i podobać się Dobroci Bożej raczej dla Niej Samej oraz dla miłości i niezrównanych dobrodziejstw, którymi nas uprzedziła, niż dla bojaźni kar lub nadziei nagrody, choć i tymi pobudkami wspierać się powinni. Trzeba ich też często zachęcać, aby we wszystkim szukali Boga, uwalniając się w miarę możności z miłości wszelkich stworzeń, tak by całą miłość przenieść na ich Stwórcę, Jego miłując we wszystkich stworzeniach, a wszystkie stworzenia w Nim według najświętszej i Boskiej Jego woli”33. Stąd też „szukać i widzieć Boga we wszystkim" to naczelna zasada, stanowiąca pewien trzon duchowości ignacjańskiej, duchowości, którą przeniknięty jest program MAGIS.

Kolejnym źródłem i inspiracją, z których czerpie omawiany program są ćwiczenia duchowe. Jak podkreślają jego twórcy, program duchowy, który chcą zaproponować młodym, powinien być pewną drogą - procesem, opartym na dynamice ćwiczeń duchowych. Ich autor, św. Ignacy „był świadom, że prawdziwa wewnętrzna przemiana człowieka to proces, który wymaga czasu i wysiłku woli w otwieraniu się na darmo daną łaskę Bożą. Jego Ćwiczenia Duchowe są tego najlepszym przykładem. Jedno ze zwięzłych ujęć dynamiki Ćwiczeń wyraża się w zwrotach: dla mnie - ze mną - we mnie. W pierwszym etapie Ćwiczeń Duchowych, jesteśmy zaproszeni do tego by pojąć i przyjąć fakt, że jesteśmy stworzeni z miłości i do wolności (fundament CD) i za darmo zbawieni z naszych grzechów (I tydzień CD). W ten sposób dogłębnie poznajemy to, co Bóg zrobił dla mnie. Następnie poprzez kontemplację tajemnic ziemskiego życia Jezusa jesteśmy wezwani (wołanie Króla) do nawiązania z Nim głębokiej przyjaźni (II tydzień CD). Przyjaźń ta przeradza się w bliską zażyłość, gdy Jezus zaprasza nas, by towarzyszyć Mu w Jego męce (III tydzień) i by mieć udział Jego paschalnej radości (IV tydzień CD). Poznajemy w ten sposób, że Bóg, wcielając się, chce się ze mną podzielić całym sobą: życiem, śmiercią i zmartwychwstaniem. Medytacja kończąca Ćwiczenia Duchowe (ad amorem - dla

32 WPM.

${ }^{33}$ Konstytucje Towarzystwa Jezusowego 288. 
pozyskania miłości) prowadzi nas do wewnętrznego zjednoczenia całego naszego życia z Bogiem. Jest zaproszeniem, aby pozwolić Bogu być, żyć i działać we mnie”34. Choć ćwiczenia duchowe, na których opiera się duchowość programu MAGIS nie są traktatem pedagogicznym samym w sobie, to jednak zawierają w sobie głębokie doświadczenie pedagogiczne wraz z elementami ściśle określonej praktyki wychowawczej. Niewątpliwie św. Ignacy posiadał pewien zmysł i zdolność umieszczenia w ćwiczeniach podstaw pedagogicznych, choć wyrażony w sposób bardziej intuicyjny i spontaniczny aniżeli systematyczny ${ }^{35}$.

Program MAGIS to w pewien sposób swoista forma dawania ćwiczeń duchowych, dostosowanych do konkretnych osób, środowiska, kontekstu społecznego i czasowego. Ćwiczenia duchowe nie stanowią bowiem monolitu i struktury, których forma nie podlega dostosowaniom i zmianom. Mówił o tym m.in. przebywający w Polsce Generał jezuitów o. Adolfo Nicolás SJ, kiedy pytany o poszukiwania nowych form dawania ćwiczeń duchowych dostosowanych do współczesnego człowieka odpowiedział: „ilość nowych form jest nieograniczona (...) św. Ignacy nie zostawił nam dwóch czy trzech sposobów dawania Ćwiczeń duchownych, ale dał nam ogromną wolność w dostosowywaniu udzielania rekolekcji ignacjańskich w szerokiej perspektywie. Pozostawił nam zasadę wolności, adaptacji, kreatywności, a nie jakieś konkretne formy. (...) W różnych domach rekolekcyjnych praktykuje się różne formy dawania Ćwiczeń: rekolekcje weekendowe, rekolekcje pięciodniowe, rekolekcje ośmiodniowe. Istnieje tu ogromna różnorodność. (...) Z kimkolwiek mielibyśmy do czynienia - z pojedynczym człowiekiem czy grupą osób - do takiej konkretnej sytuacji możemy dostosować formę dawania Ćwiczeń duchownych według metody św. Ignacego Loyoli.(...) Niezależnie od sytuacji metoda udzielania Ćwiczeń duchownych musi być zawsze realistyczna, musi dotrzeć do serca człowieka, bo w sercu jest dynamika, która nas porusza"36.

Ćwiczenia duchowe świętego Ignacego wychowują dziś jezuitów i kształtują każdego odprawiającego rekolekcje ignacjańskie. To poprzez osobistą modlitwę

\footnotetext{
34 WPM. Autorzy WPM rozwijają tę myśl stwierdzając, iż „podczas Ćwiczeń Duchowych Bóg przez 30 dni nam mówi (a my uważniej niż w codzienności słuchamy): z miłością zechciałem abyś żył(a) i był(a) wolny(a) [fundament] i nie zmieniam tej mojej decyzji nawet gdy ty ją najbrutalniej odrzucasz [I tydzień]. Choć wiem, że jesteś słaby(a), to i tak chcę byśmy byli przyjaciółmi (wołanie Króla). Nie mam przed tobą nic do ukrycia: chcę byś był(a) przy moich narodzinach i towarzyszył(a) mi w różnych przygodach mojego życia (II tydzień), bardzo pragnę byś był(a) przy mojej śmierci (III tydzień) i byś wraz ze mną cieszył(a) się moim zmartwychwstaniem (IV tydzień). Jak to wszystko ze Mną przejdziesz, poznasz też, że i ja zawsze jestem przy tobie i uwierzysz, że przeprowadzę cię ze śmierci do wiecznego życia (ad amorem)".

35 Por. W. Królikowski, Cele i etapy formacji duchowej w pedagogice ignacjańskiej, w: Pedagogika ignacjańska. Historia. Teoria. Praktyka, dz. cyt., s. 24.

36 A.Nicolas, Spotkanie z jezuitami pracujacymi w Domach Rekolekcyjnych i współpracownikami. Gdynia 24 września, w: Wizyta Ojca Generała Adolfo Nicolasa SJ w Polsce. 23-30 września 2012 roku, 2013, s. 20.
} 
(medytację), refleksję i Eucharystię człowiek spotyka się z Bogiem, jednocześnie lepiej poznaje siebie. I właśnie w programie MAGIS dzięki połączeniu doświadczenia oraz modlitwy młodzi mają możliwość poznać swoje reakcje w różnych sytuacjach. Nabyte w ten sposób doświadczenia pomagają sprostać nowym życiowym wyzwaniom. Młodzi ludzie uczestniczący w ignacjańskich eksperymentach nie tylko pogłębiają relację z Bogiem ale także poprzez modlitwę i dzielenie uczą się wprowadzać Słowo Boże w czyn ${ }^{37}$.

Jezuicki program MAGIS 2016 to jedna z propozycji formacji katechetycznej ludzi młodych uczestniczących w Światowych Dniach Młodzieży. Niewątpliwie jest to propozycja formacji, która jest „katechezą dla młodzieży w nowym kształcie, otwartą na wrażliwość i problemy jej wieku, które mają charakter teologiczny, etyczny, historyczny, społeczny" "38 a jednocześnie katechezą, która szczególne miejsce przyznaje „wychowaniu w prawdzie i wolności zgodnie z Ewangelią, formacji sumienia, wychowaniu do miłości, problematyce powołaniowej, zaangażowaniu chrześcijańskiemu w społeczeństwie, odpowiedzialności misyjnej w świecie" 39 . Program MAGIS, jak wskazuje już sama etymologia jego nazwy, wywodzącej się z ignacjańskiej zasady dążenia do doskonałości, ciągłego postępu, ciągłego dążenia do tego, co lepsze, owocniejsze i doskonalsze ${ }^{40}$ to także „dążenie do zrozumienia znaczenia czynów i słów Chrystusa, oraz znaków dokonanych przez Niego, po-

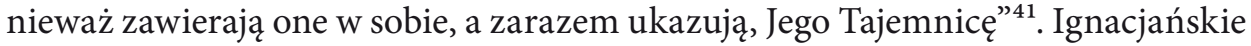
eksperymenty poprzez swoją różnorodność stanowią jednocześnie odpowiedź na potrzebę wprowadzania w katechezie różnych metod stosownych do wieku i rodzaju umysłowego katechizowanych, dojrzałości eklezjalnej i duchowej oraz indywidualnych uwarunkowann ${ }^{42}$. Założenia, forma i cele jezuickiego programu MAGIS 2016 pozwalają mieć nadzieję, iż Światowe Dni Młodzieży w Krakowie nie pozostaną jednorazowym wydarzeniem katechetycznym ale głębokim doświadczeniem, które będzie inspiracją dla ludzi młodych do ciągłego odnajdywania Boga we wszystkim.

\section{Streszczenie}

Artykuł przedstawia jezuicką propozycję formacji ludzi młodych przybywających na Światowe Dni Młodzieży. MAGIS 2016 to wynik refleksji Towarzystwa Jezusowego nad tym, jak wykorzystać okazję Światowych Dni Młodzieży do bycia z ludźmi młodymi

37 Por. WPM.

38 DOK 185.

39 Por. Tamże.

40 E. Dybowska, Pedagog - lider w pedagogice ignacjańskiej, w: Pedagogika ignacjańska. Historia.

Teoria. Praktyka, dz. cyt., s. 262.

41 CT 5.

42 Por. CT 51. 
i jednocześnie przygotować ich do udziału w nich. MAGIS 2016 jest organizowany przez Jezuitów, w ich polskich prowincjach, wraz z innymi zgromadzeniami zakonnymi żyjącymi duchowością ignacjańską oraz grupami świeckich i prowincjami jezuickimi w Europie. Jest on koordynowany przez grupę jezuitów, wolontariuszy oraz grupy świeckich pracujących w różnych częściach Polski. Mottem programu jest zdanie z modlitwy o hojność św. Ignacego: „dawać, a nie liczyć”. Podczas MAGIS 2016, proponowane eksperymenty są wyzwaniem do dzielenia się, świętowania, udziału oraz do zaangażowania się i przemiany.

Słowa klucze: Światowe Dni Młodzieży, magis, eksperymenty ignacjańskie, pedagogika ignacjańska.

\section{MAGIS 2016 - JESUIT PROPOSAL FOR THE FORMATION OF THE YOUNG PEOPLE PARTICIPATING IN WORLD YOUTH DAY}

\section{Summary}

This article presents a Jesuit proposal for the formation of young people coming to the World Youth Day 2016. MAGIS 2016 is the result of reflection of the Society of Jesus on how to take the opportunity of World Youth Day in order to be with the youth and at the same time prepare them to participate in it. MAGIS 2016 is organized by the Society of Jesus through its Jesuit provinces in Poland together with other religious congregations of Ignatian spirituality, secular groups and Jesuit provinces of Europe. It is coordinated by a group of Jesuits, volunteers and various teams working in different parts of Poland. The motto of MAGIS 2016 is a phrase from the Prayer for Generosity of St. Ignatius: 'To give and not to count the cost. During MAGIS 2016, the proposed experiments are to stimulate sharing, celebrating, engaging, participation and transformation.

Key words: World Youth Day, magis, ignatian experiment, Ignatian pedagogy. 